\title{
Institutional Effects on the Careers of State Supreme Court Justices
}

\author{
Todd A. Curry \\ University of Texas at El Paso \\ Mark S. Hurwitz \\ Western Michigan University
}

\begin{abstract}
We contend a direct connection exists between risk of removal from the bench and the length of judicial careers, as institutional mechanisms present varying but predictable degrees of risk to justices. Using event history modeling, we analyze the duration of judicial tenures and resultant levels of risk provided by selection methods. We demonstrate that justices in partisan elections have the shortest tenures and greatest risk of departure. By contrast, justices in the Missouri Plan evidenced the longest careers, offering a trivial amount of risk to justices. We show that the length of judicial careers are, in part, a function of the institutional design of selection and retention systems.
\end{abstract}

The 2010 Supreme Court retention elections represented an entirely unique event for Iowa's judicial branch. For the first time since the installation of retention elections in 1962 an Iowa supreme court justice failed to be retained at the polls. Incredibly, three justices, including Chief Justice Marsha K. Ternus, Justice Michael J. Streit, and Justice David L. Baker, were not retained by the voters that year. An expensive campaign, in large part funded by the National Organization for Marriage and the American Family Association, painted all the justices on the Iowa Supreme Court as liberal extremists out of touch with the citizens of Iowa. Arguing that the justices' decision in Varnum v. Brien $\left(763\right.$ NW $\left.2^{\text {nd }} 862,2009\right)$ which overturned a statute banning gay marriage did not represent the values of Iowans, the campaign urged voters to remove the three justices standing for retention. And the voters listened.

In turn, so did political scientists who study methods of retention for state supreme courts. Retention elections are generally not newsworthy events. Indeed, the last time a retention election received national news coverage was during 1986 when voters removed Chief Justice Rose Bird and three colleagues from the California Supreme Court. Said more simply, it is very rare that individual justices are removed from office in retention elections (Kritzer 2015).

The retention elections employed in Iowa and California are an element of the judicial selection system known as the Missouri Plan. Under this method of selection the governor appoints justices from a list of nominees recommended by a judicial commission; then, after a prescribed period of time serving on the bench, those justices are subject to an uncontested retention election. Advocates of the Missouri Plan support this selection system because they claim it enhances the goal of judicial independence (Hall 2001). Nevertheless, as envisioned by one of its most vocal proponents, the American Judicature Society (AJS) has contended that 
retention elections are designed to be used much like impeachment, but not for ideological voting as occurred in Iowa in 2010. ${ }^{1}$

Proponents of merit-based selection, including the AJS and American Bar Association (ABA) among others, seek to maximize judicial independence in order to shield judges from inappropriate external influences when interpreting the law (Graves, Howard, and Corley 2014). Notwithstanding the 2010 results in Iowa, these advocates favor the Missouri Plan because they believe that choosing and retaining judges in this manner enables them to make decisions that are free from political or electoral constraints, thus augmenting judicial independence.

On the other hand, enhanced accountability is a critical element for those in favor of judicial elections. That is, because these judges must stand for election, there is a greater likelihood they will be held answerable for their judgments. In fact, this seems to be the preference of voters (Gibson 2012). If a judge makes decisions out of tune with the prevailing political mainstream within a state, the electoral mechanism provides the public with a means of removal and replacement, thus enhancing accountability (Bonneau and Hall 2009; Dubois 1980).

Our analysis assesses one particular aspect of the judicial career: how the institutions of selection and retention distribute the risk of removal from the bench and thus influence judicial tenure. We believe that the length of the judicial careers, when aggregated, is associated with judicial accountability. The literature provides abundant examples of the influence of selection systems on judicial outcomes, particularly with respect to decision making (e.g., Brace and Boyea 2008; Brace and Hall 1990; Hall 1995). ${ }^{2}$ Moving beyond decision making, we are interested in studying observable differences in judicial careers contingent on methods of selection and retention. Accordingly, we empirically examine whether disparate selection methods systematically affect the length of careers of state supreme court justices. By doing so we are able to analyze the institutions which provide for the most accountable selection and retention methods. Although accountability is a complex concept, we agree with institutional designers who expect a direct connection between the amount of risk of removal and judicial accountability. Accordingly, we seek to analyze the likelihood of removal from the bench. ${ }^{3}$

\section{Judicial Selection, Careers, and Risk}

During the country's infancy, some states followed the federal model of judicial appointment, but others did not. Mississippi was the first state to adopt elections for all its courts in 1832 (Shugerman 2012). Apparently in the wake of Jacksonian democracy, many states soon embraced elections, particularly partisan elections. According to Haynes (1944, 100): "In the year 1850 alone, seven states changed to popular election of judges." In reaction to this trend

\footnotetext{
${ }^{1}$ Advocates of the Missouri Plan often refer to this selection system as the merit system (e.g., Caufield 2012), while others (usually scholars) refer to it as the Missouri Plan, the state credited as the first to implement this system in 1940 (Wheat and Hurwitz 2013). We use the terms Missouri Plan and merit system interchangeably.

${ }^{2}$ The influence of selection systems on decision making is not limited to judicial politics (see Burden et al. 2013)

${ }^{3}$ In addition to claims of independence, legal and political elites assert that the Missouri Plan enhances, while elections detract from, judicial legitimacy (Caufield 2007; see also Ansolabehere et al. 1994). Notwithstanding, Gibson $(2012,111)$ provides empirical support that "politicized campaigning is unlikely to affect legitimacy" (see also Gibson 2009; Hall and Bonneau 2013). While judicial legitimacy is tangentially related to our study, we are concerned specifically with the concepts of accountability and independence based on judicial careers.
} 
favoring judicial elections, an opposing drive by advocates of reform in the early twentieth century endorsed what they since have termed merit selection. Reformers (such as the AJS and ABA) sought to lessen political influence on courts, which they believed stemmed from inappropriate electoral influences (Caufield 2012). Over time many states agreed, choosing to utilize some form of the Missouri Plan, now the most popular selection method in state appellate courts. Notwithstanding, numerous other states continue to employ competitive elections, which remain a very popular method of judicial selection (Hurwitz and Lanier 2008; Streb 2007).

In addition to electoral and merit systems of selection, governors and legislatures have the power to appoint judges in several states. Judicial appointment by these political elites is often deemed similar to the Missouri Plan in terms of the purposes behind these selection systems, in part because some consider all of these systems to be appointive in nature (Berkson 1980). That is, it is thought that appointive systems tend to promote judicial independence more so than electoral systems. The institutional differences are that justices in gubernatorial and legislative appointive systems generally are not subject to the voting public's confidence, nor in most states are they initially chosen by a commission, as are justices in a Missouri Plan.

The consequence is a multiplicity of selection methods in the states today. While these mechanisms differ by state, such that nearly each state's selection system is unique, the literature considers five broad, institutional selection methods: partisan elections, nonpartisan elections, gubernatorial appointment, legislative appointment, and the Missouri Plan (Glick and Vines 1973). There is a tradition of debate on the perceived benefits and burdens of the assorted means of selection. Indeed, to assert there is a controversy over methods of judicial selection and retention would downplay the current landscape, in terms of both numbers of players and level of rhetoric. A critical reason for the intensity of debate is that selection and retention systems play directly into the normative issue of whether judges should be independent or accountable. Some argue that accountability via public participation is essential to all democratic institutions, including the judiciary (Bonneau and Hall 2009, 2013; Hall 2001). Others contend that judicial independence must be preserved by ridding the judiciary of elections (ABA 2003; Caufield 2012; O'Connor 2003). As there is much at stake when it comes to selection and retention systems, the terms of the debate tend to plunge into a level of hyperbole, often (but not always) with claims made based on a lack of empirical research to support those conclusions.

As this debate has been constructed, conventional wisdom holds that elections promote accountability, while appointive and Missouri Plan systems advance independence. While some studies merely look at defeat rates in a given year, we argue that judicial tenure and the risk of removal from office over time is a more accurate proxy for judicial accountability. The question thus becomes whether the several methods of selection and retention in fact produce distinctive influences on judicial accountability.

Our purpose is to analyze the various systems of judicial selection and retention by comparing the tenure lengths of state supreme court justices across disparate selection systems. More particularly, do the several systems of selection and retention systematically distribute risk and affect judicial careers? Our modeling strategy assumes at its core that each justice is constantly at risk to leave the bench. We make the second, complementary assumption that the risk of leaving the bench is conditioned upon the method of selection and retention. As Hall $(2001,1136)$ asserted in her study on how electoral pressures influence state judges to retire: 
"This study is only the first that seeks to unravel the fascinating and complicated nexus between democratic processes and career decisions in the states' highest courts. Countless questions remain [and] further inquiry will be fruitful, especially for examining and perhaps dispelling myths surrounding the politics of institutional design" (see also Curry and Hurwitz N.d.) In accepting this invitation, we further this line of research by examining whether distinct selection systems influence the lengths of judicial careers.

\section{Judicial Careers and Theoretical Expectations for Leaving the Bench}

For purposes of this study, we consider risk to be related to the length of tenure for a justice on a state court of last resort. This recognizes that increased risk of losing one's position on the bench produces shorter tenures, a concept which is intuitively related to accountability. As Hall (2007b, 165) provided, "accountability can be defined in numerous ways," and thus we employ tenure length as a proxy for analyzing differences in judicial accountability. ${ }^{4}$ Differences in judicial tenure do not translate to a one-to-one measure of differences in judicial accountability. We believe, and we think reformers on both sides of the current debate would agree, that variations in judicial tenure across different selection and retention systems will tell us a portion of the story concerning accountability and independence. Our measure is not perfect, but its conceptualization is novel and quite observable.

With this view of risk in mind, our theoretical expectations are based in part on an institutional perspective (Bonneau and Cann 2011, 2015; Brace and Boyea 2008; Hall 2001) and on conventional wisdom, both of which interestingly coincide here. From an institutional perspective, the several methods of selection should produce variable levels of risk of removal in predictable ways, based on the unique institutional arrangements of each system (Curry and Hurwitz N.d.). These institutions, therefore, should have expected influences on the tenure length of justices.

As well, conventional wisdom plays a role in our expectations regarding tenure length. There is much discussion and debate, scholarly and otherwise, regarding perceived advantages of different selection systems based on notions of accountability and independence. Yet, advocates and opponents of judicial elections generally agree that judges who stand for some form of election are more likely to be held accountable than those in appointive systems. Indeed, this concept forms the basis of Hall's (2001) electoral vulnerability hypothesis, which serves as a starting point for our theoretical expectations. Stated otherwise, due to the institutional features of competitive elections, judges exposed to elections should be at greater risk of being forced off the bench than their appointed colleagues ${ }^{5}$.

The probability of risk - and thus the greatest potential for shorter careers - should be highest in partisan elections. As Hall showed (2007a, 1151): "voters vote when they have

\footnotetext{
${ }^{4}$ Of course, there are other facets of, and proxies for, judicial accountability (e.g., Hall 2007b); however, tenure length is one particularly instructive manner of addressing this concept.

${ }^{5}$ While judicial accountability and independence are often deemed mutually exclusive of each other, we contend instead that these are multi-faceted concepts, aligning along a continuum rather than an either/or proposition. That is, all institutions produce degrees of accountability and independence (Clark 2011). The question for us is, which selection and retention methods tend to promote more (or less) accountability relative to the others? Our expectations about tenure length and systems of selection and retention are based on this conceptualization.
} 
interest, readily available information, and choice." Such increased interest and information peak in partisan elections, because: 1) partisan elections generate the most expensive campaigns, which increase the electorate's access to information and turnout (Baum and Klein 2007; Bonneau and Hall 2009); and 2) partisan elections potentially field high quality challengers, which increase information and choice (Hall 2015; Hall and Bonneau 2006, 2008). At a minimum, because candidates are listed on the ballot with their partisan affiliation, a key source of information is revealed to voters in partisan elections (Downs 1957). Accordingly, we posit that justices subject to partisan elections face the highest probability of risk; as a consequence, we expect justices in partisan elections to display the shortest lengths of tenure.

Nonpartisan elections are near structural mimics of their partisan counterparts in terms of competitive features; indeed, the only difference is that the candidates' partisan affiliation is not listed on the nonpartisan ballot. Without this critical partisan cue, and because nonpartisan campaigns are generally less expensive than partisan campaigns, voters have comparatively less information and interest in nonpartisan elections (Bonneau 2005). Accordingly, we hypothesize that nonpartisan electoral systems should produce relatively high levels of risk and short tenure lengths; however, since the likelihood of risk is lower due to decreased information and money, we expect that tenure length should be longer in nonpartisan elections relative to partisan elections (Hall 2007b; Hall and Bonneau 2008).

While retention elections found in traditional Missouri Plans are not associated with the levels of risk inherent in competitive (i.e., partisan or nonpartisan) elections, advocates make clear that retention elections provide voters with the ability to hold judges accountable, claiming that non-contested retention elections provide an accountability function which appointive systems lack, to wit: "retention elections effectively allow the public to exercise 'veto' authority by removing judges from office" (Caufield 2012, 5). Under this line of reasoning, the expectation would be that the Missouri Plan produces less accountability than partisan or nonpartisan elections, but more accountability than appointive systems.

However, judicial reformers may erroneously assume that uncontested retention elections provide a significant level of risk. Iowa 2010 notwithstanding, retention elections are generally low-salience affairs featuring little to no campaigning, as voters receive at most a modicum of information about their voting decision (Kritzer 2015). We thus observe high levels of ballot roll-off in retention elections, in some cases as large as 50 percent or more from the top of the ballot (Bonneau and Cann 2015; Bonneau and Hall 2009; Dubois 1979; Klein and Baum 2001). ${ }^{6}$ Consequently, nearly all incumbents in Missouri Plan systems are retained. Thus, scholarship on judicial elections (and elections more generally, e.g., Vanderleeuw and Engstrom 1987) differs from the rhetoric of reform advocates. We follow the lead of these political scientists, eschewing the claims of judicial reform groups, and posit that the accountability function within retention elections is muted; consequently, justices subject to the Missouri Plan should have longer tenures than justices in the other selection and retention systems.

Where do appointive systems fit within these hypotheses? Appointed justices' retention is tied to the partisan interests of the executive or legislative branch of state government. This

\footnotetext{
${ }^{6}$ While other electoral systems experience ballot roll-off, it is not systematic. If there is contestation, ballot roll-off reduces significantly. As contestation is not possible in retention elections, the ballot roll-off experienced is systematic (Bonneau and Hall 2009; Hall 2015).
} 
creates an environment that may indeed be hostile to the interests of an incumbent. While Langer (2002) showed that justices often behave so as not to garner retribution from the appointing institution, political elites with the power of reappointment are active observers of the judicial branch. Governors may fail to reappoint, or their pressure could force justices to retire (Curry and Hurwitz N.d.; Hall 2001). Consequently, we hypothesize that justices in appointive systems should exhibit higher levels of risk, and thus shorter tenures, than those in the Missouri Plan, though less risk than we expect in partisan and nonpartisan electoral systems.

In sum, the methods of selection and retention employed in state supreme courts should affect the tenure of justices in predictable ways, with institutional arrangements subjecting the justices to varying levels of risk and consequent lengths of tenure. Our hypothetical rank order is found in Table 1. In particular, we expect justices will be most at risk of leaving the bench in competitive partisan and nonpartisan elections, with partisan elections providing the greatest risk and thus shortest tenures. We also expect appointive methods to fall next along the range of risk, with tenure lengths longer than those in competitive elections but shorter than those in the Missouri Plan's non-competitive retention elections. However, judicial reform groups would expect otherwise, based on their claims that retention elections in the Missouri Plan provide ample levels of accountability. We accordingly enter this debate not to take any particular side, but instead to analyze testable hypotheses of accountability generated by the institutions of selection systems. Consequently, we examine whether disparate mechanisms of selection and retention produce varying lengths of judicial careers.

\section{Specifying Models of Tenure Length of State Supreme Court Justices}

In order to analyze whether selection and retention systems systematically influence judicial careers, we collected data on the length of tenure for every individual state supreme court justice who served in one of sixteen states from 1980-2005. We categorized each state as employing one of the following institutional methods of retention: 1) partisan election, 2) nonpartisan election, 3) retention election, and 4) appointment. We selected the particular states in our study because all of them incorporate classic features of the respective selection and retention systems without significant modification for the entire sample period of our study. While the states chosen for partisan election and legislative selection were not random (as there are only four and two respectively), each other the other systems were randomized with certain conditions. They could not employ lifetime tenure, nor could they have switched method of 
Table 1. Theoretical Expectations

\begin{tabular}{|c|c|}
\hline Rank Ordering of Selection Methods from Most to Least Risk of Departure:* \\
\hline Partisan Elections & Most \\
\hline Nonpartisan Elections & Second \\
\hline Appointive Systems & Third \\
\hline Retention Elections (Missouri Plan) & Least \\
\hline Expected Direction of Control Variables:** & \\
\hline Gender & 0 \\
\hline Minority & 0 \\
\hline Age at Selection & + \\
\hline Retirement Age & + \\
\hline Ideological Distance & + \\
\hline
\end{tabular}

*Most accountable selection systems are defined by the shortest judicial tenures, while least accountable are defined by the longest judicial tenures.

** Gender is coded 1 if female, 0 if male; Minority is coded 1 if Non-White, 0 if White;Age at Selection is coded in years; Retirement Age is coded 1 if mandatory retirement age exists, 0 otherwise; Ideological Distance is a time-varying covariate measuring the distance between a justice's PAJID (Brace, Hall, and Langer 2000) score and the state's respective Berry et al. (1998) score.

selection or retention during our timeline. This allows us more specifically to test our hypotheses. We chose four states from each selection system so that all of the categories would be equally represented. Table 2 presents the states we analyze and their respective methods of selection and retention. ${ }^{7}$

Table 2 also displays the number of justices and departures for each state in our study inclusive of 1980-2005. A departure occurs when a justice leaves the bench during the period of analysis for any reason, which might include retirement, resignation, loss of an election, failure to be reappointed, or death. We are most interested in departures, since we anticipate that the

\footnotetext{
${ }^{7}$ We are somewhat limited in our choice of states. Eleven states changed from one selection mechanism to another during our period of study, while numerous others utilized systems that include features of different methods, or they provided life tenure for their justices, rendering each of these states unsuitable for our analysis. Moreover, we chose four states from each category because only the four states in our sample employed partisan elections for the entire duration of our study. In our analysis the Missouri Plan is represented by retention elections. We aggregate gubernatorial and legislative appointment into a single "appointment" category because only two states used legislative appointment and only a few more employed gubernatorial appointment. As well, gubernatorial and legislative selection methods are appointive in nature, providing theoretical justification to combine them (see Curry and Hurwitz N.d.).
} 
time a justice leaves the bench is conditioned by her institutional selection system. Of course, justices may leave the bench for reasons unrelated to the risks levied upon them by the system in which they serve. However, there is no theoretical reason to assume that these departures are unevenly distributed across the several methods of selection. Stated otherwise, a justice in a partisan electoral system should be no more likely to die than if she were in an appointive system. Similarly, justices depart state courts seats by resigning due to nomination to a federal court from each selection system in relatively equal proportions. ${ }^{8}$ Therefore, if we assume that departures of these types are unrelated to the method of retention used, the remaining variation should be a function of the method of retention and our statistical controls.

There are valid, theoretical grounds to assume that retirements and resignations would be related to selection methods. As Hall (2001) asserted, decisions to leave the bench are motivated by perceived electoral fortunes; hence, these departures may not be uniformly distributed across the several systems. Indeed, our theory on the distribution of risk to justices' careers incorporates the idea that such departures are conditioned upon the institution of selection and retention (Curry and Hurwitz N.d.). Within systems that use elections, Hall (2001) demonstrated that justices who perceive themselves vulnerable to an electoral defeat are more likely to retire from the bench. In appointive systems, Langer (2002) found that justices strategically augment their decision making when there is a fear of reprisal in terms of their retention. And, Curry and Hurwitz (N.d.) found that state supreme court justices retire strategically as a function of their particular selection and retention system. This shows justices are cognizant of their likelihood of retention, and thus we would expect them to take steps to increase that likelihood, or to retire before they can be removed. Although the motivation is different in electoral and appointive mechanisms, our theory recognizes that some (though clearly not all) retirement decisions should be related to the justice's retention system.

We operationalize the dependent variable in our study, Tenure Length, as the length of time a justice served on the bench in a state supreme court. In order to assess the effect of selection methods upon our Tenure Length variable, we incorporate substantive independent variables representing the several selection and retention methods, represented as Partisan Election, Nonpartisan Election, Retention Election, and Appointment. We also include three dichotomous control variables: Gender (Female or Male), Minority (non-White or White), and if a state imposed a Retirement Age. We have no expectation whether or how gender or minority status might influence judicial tenure, as the literature is unclear on these variables and their effects; however, we include these controls since the empirical question should be examined in a fully-specified model. However, we expect that justices in states that impose a mandatory retirement age should experience shorter judicial tenures than those that do not. Age at Selection is also included for a more fully-specified model, as individuals who enter the bench when older

\footnotetext{
${ }^{8}$ In our sample, seven percent of justices in partisan systems departed their seats when nominated to the federal bench, which is not statistically different (taking sample size into account) from the nine percent in nonpartisan, eight percent in appointive, and four percent in Missouri Plan systems nominated to a federal court.
} 
Table 2. Descriptive Statistics (1980-2005).

\begin{tabular}{|c|c|c|}
\hline States & $\begin{array}{l}\text { Number of } \\
\text { Justices }\end{array}$ & $\begin{array}{l}\text { Number of } \\
\text { Departures }\end{array}$ \\
\hline \multicolumn{3}{|l|}{ Partisan Election States: } \\
\hline Alabama & 31 & 22 \\
\hline Louisiana & 18 & 11 \\
\hline Texas & 44 & 34 \\
\hline West Virginia & 19 & 14 \\
\hline \multicolumn{3}{|l|}{ Nonpartisan Election States: } \\
\hline Kentucky & 21 & 13 \\
\hline Oregon & 24 & 17 \\
\hline Washington & 29 & 19 \\
\hline Wisconsin & 18 & 11 \\
\hline \multicolumn{3}{|l|}{ Retention Election States (Missouri Plan): } \\
\hline Iowa & 20 & 13 \\
\hline Kansas & 18 & 11 \\
\hline Oklahoma & 18 & 9 \\
\hline Nebraska & 20 & 13 \\
\hline \multicolumn{3}{|l|}{ Appointive States: } \\
\hline Maine (Gubernatorial Appointment) & 22 & 16 \\
\hline New Jersey (Gubernatorial Appointment) & 19 & 12 \\
\hline $\begin{array}{l}\text { South Carolina (Legislative } \\
\text { Appointment) }\end{array}$ & 14 & 8 \\
\hline Virginia (Legislative Appointment) & 19 & 12 \\
\hline Totals: & 351 & 232 \\
\hline
\end{tabular}


are less likely to serve as long as those who are younger. Our final independent variable, Ideological Distance, is a time-varying covariate (TVC) that operationalizes the absolute value of the difference between the justice's PAJID score (Brace, Langer, and Hall 2000) and the state's respective Berry et al. (1998) score. For states utilizing partisan, nonpartisan, or retention elections we employ the Berry citizen ideology scores, while for appointive states we apply the Berry government ideology scores. As those who study state courts are aware, PAJID scores measuring state judicial ideology are on a common metric with Berry scores quantifying the ideology of a state's elite and electorate. We include Ideological Distance in our model to ascertain whether the dynamic effects of ideology serve as a potential influence on judicial tenure as it does on decision making (Brace and Boyea 2008). While the distance score is compiled using different particularized measures, we feel it specifically taps our hypothesis, namely, that as justices become more ideologically distant from the body responsible for their retention (be it the public, the governor, or the legislature), they will be more likely to leave the bench. Table 1 additionally illustrates these theoretical expectations.

The appropriate statistical method to analyze data of this sort is an event history model, also known as a hazard model (Collett 2003). There are numerous hazard models from which to choose, based on the assumptions of the model and the data utilized. We employ a Cox proportional hazard model (Cox 1972), a semi-parametric technique that assumes no a priori expectation concerning the shape of the duration dependency. A parametric model, which assumes specific distributions of the hazard function, would be appropriate if we had such an expectation. Instead, we assume that the hazard rate differs in predictable ways across the various methods of selection and retention, not that the hazard rate has a specific distributional form. Thus, a Cox proportional hazard model (hereafter, "hazard model" or "Cox model") is most appropriate for our research design (Box-Steffensmeier and Jones 2004).

Political scientists have utilized event history models to examine temporally-ordered data in myriad contexts, (see Box-Steffensmeier and Jones 2004; Box-Steffensmeier and Zorn 2001), including Cox hazard models in research on judicial politics (see, e.g., Curry and Hurwitz N.d.; Langer et al. 2003; Shipan and Shannon 2003). Our research examining the duration of state supreme court justices' tenure is methodologically analogous to these studies. ${ }^{9}$

With event history models, issues of left truncation and right censoring must be addressed. Left truncation concerns individual who joined the risk pool prior to the first observation, which is 1980 in our analysis. These justices do not enter at $t=0$ but instead at the time in which they enter the risk pool (such as $t=8$, etc.). With right censoring, a justice continues on the bench after our period of analysis in 2005. In this context, they provide information to the model until the point they are no longer observed (Box-Steffensmeier and Jones 2004).

"The Cox Model assumes that the hazard function of any two individuals with different values on one or more covariates differ only by a factor or proportionality" (Box-Steffensmeier and Zorn 2001, 974). If this assumption is violated, then the Cox Model could be biased. Following the lead of Box-Steffensmeier and Zorn, we examined the assumption of

${ }^{9}$ Examples of studies in judicial politics that employ event history models other than Cox proportional hazard models include Patton (2007) and Savchak et al. (2006). 
proportionality by testing the scaled Schoenfeld residuals and found no evidence of nonproportionality. Furthermore, it is appropriate to cluster the standard errors to obtain more accurate estimates of empirical reality. Since variation within each state may systematically affect the duration, we cluster the standard errors on the state. We now examine the Cox models in order to analyze accountability across selection systems.

\section{Results}

Figure 1, which illustrates mean judicial tenures of state supreme court justices as a function of selection and retention system, displays the variability of tenure across the several institutions. In particular, justices in partisan electoral systems exhibit the shortest tenures, while their brethren in the Missouri Plan (via retention elections) serve for the longest duration of time.

\section{Figure 1. Mean Tenure of State Supreme Court Justices as a Function of Selection and Retention Systems.}

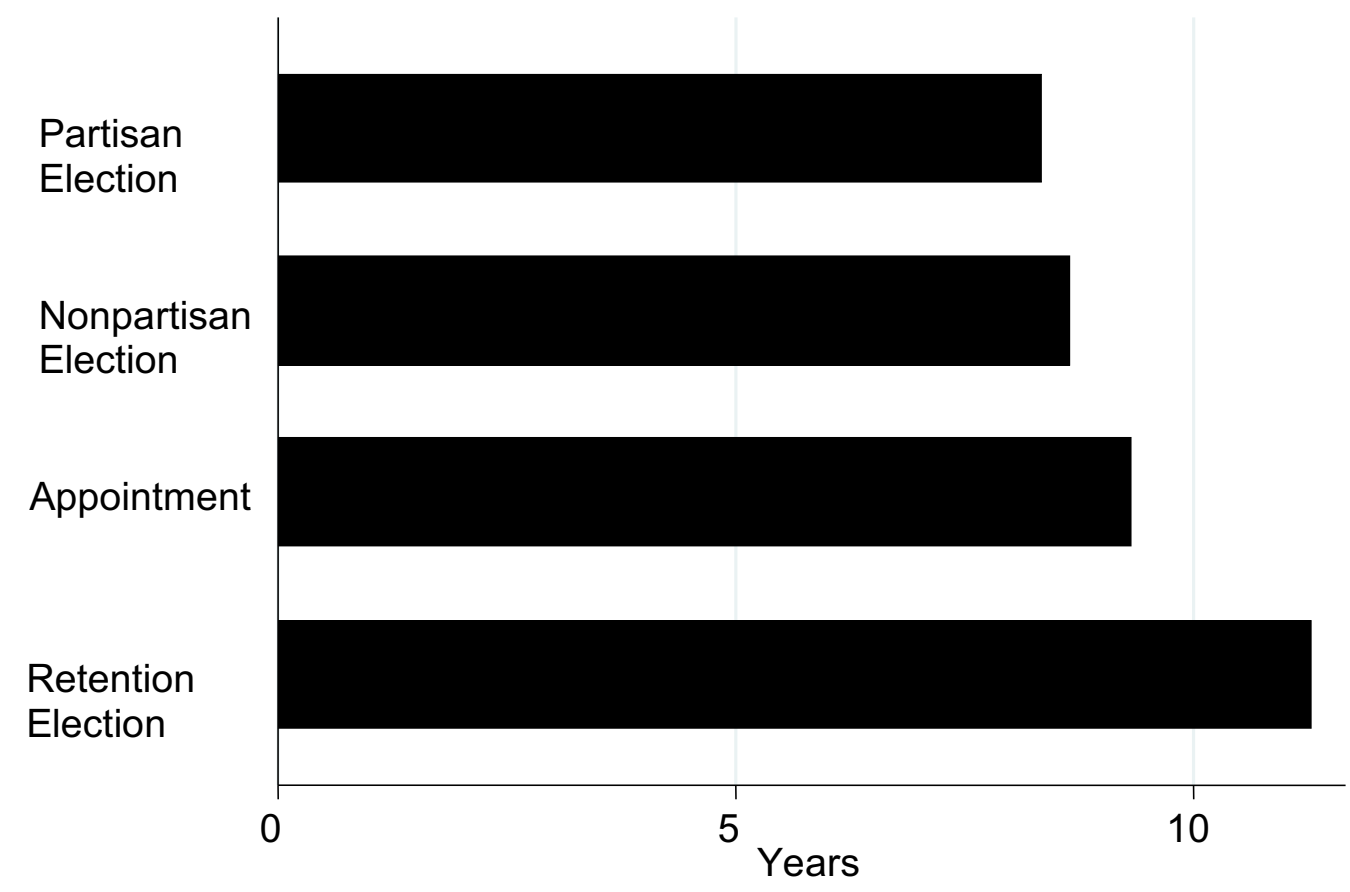

These findings lend initial support for our theory based on tenure length as a proxy for accountability. This figure suggests that competitive elections produce the most risk of leaving the bench, while appointive systems afford slightly more risk than retention elections. In fact, a justice within a partisan election system can expect her tenure to be about 25 percent shorter than 
justice subject to a retention election. ${ }^{10}$

With these descriptive results in hand, the first step in testing these hypotheses for systematic effects is to examine whether the survivor functions of the methods of selection are equal. Collett (2003) demonstrates that the log-rank test provides for such a test by pitting the hypotheses against the null hypothesis that there is no difference between the survivor functions of the four selection systems. The log-rank test displayed in Table 3 shows that the survivor functions of the different systems are clearly discrete; thus, the null hypothesis of no difference among them can be rejected, since observed departures are significantly different from expected departures.

Table 3: Log-Rank Test for Equality in the Survivor Function.

\begin{tabular}{|lcc|}
\hline \hline \multicolumn{1}{c}{ Selection Method } & Departures Observed & Departures Expected \\
\hline \hline Partisan Election & 81 & 54.31 \\
Nonpartisan Election & 60 & 58.29 \\
Appointment & 46 & 51.19 \\
Retention Election & 45 & 68.20 \\
\hline
\end{tabular}

Null hypothesis: equal departures expected.

Chi2(3) $=23.77$

$\operatorname{Pr}>\chi^{2}=0.00$

The Kaplan-Meier survivor function is a similar test that can be assessed graphically (Box-Steffensmeier and Jones 2004), as shown in Figure 2. The survivor functions demonstrate that the methods of selection are largely distinct from each other. Moreover, Figure 2 provides further evidence that retention elections have the least amount of risk, as evidenced by the Kaplan-Meier survivor function that decreases most slowly (signifying the longest tenure) for this selection system; moreover, it shows that partisan elections produce the maximum amount of risk for justices. Therefore, we can reject the null hypothesis of equal risk across these selection and retention systems, since the survivor functions are statistically different from each other. We now move on to the next step in the analysis.

While the log-rank test and Kaplan-Meier survivor function provide information on the duration of the data, neither allows for direct comparisons of change in the hazard rate across the

\footnotetext{
${ }^{10}$ The results for mean tenure length of justices presented in Figure 1 are even more striking when mean term length of the several selection systems is taken into account. To clarify, term length is the legally specified term of office for any justice (which ranges from six - 12 years), while tenure length is the actual length of time a justice served on the bench. In our sample, mean term lengths are: Retention Election $=6.5$ years; Nonpartisan Election=7.5 years; Partisan Election=8.5 years; Appointment $=9$ years. This reveals that justices subject to the shortest term lengths, the Missouri Plan's Retention Elections, in fact serve lengths of tenure far longer than justices in the other systems.
} 
methods of selection. For this purpose we employ the Cox model, which specifically affords direct comparisons in rates of change of tenure across time. In particular, this hazard model allows us to "determine if a variable increases duration by looking at its effect on the baseline hazard rate" (Shipan and Shannon 2003, 662).

Figure 2: Kaplan-Meier Test of Survivor Function Estimates.

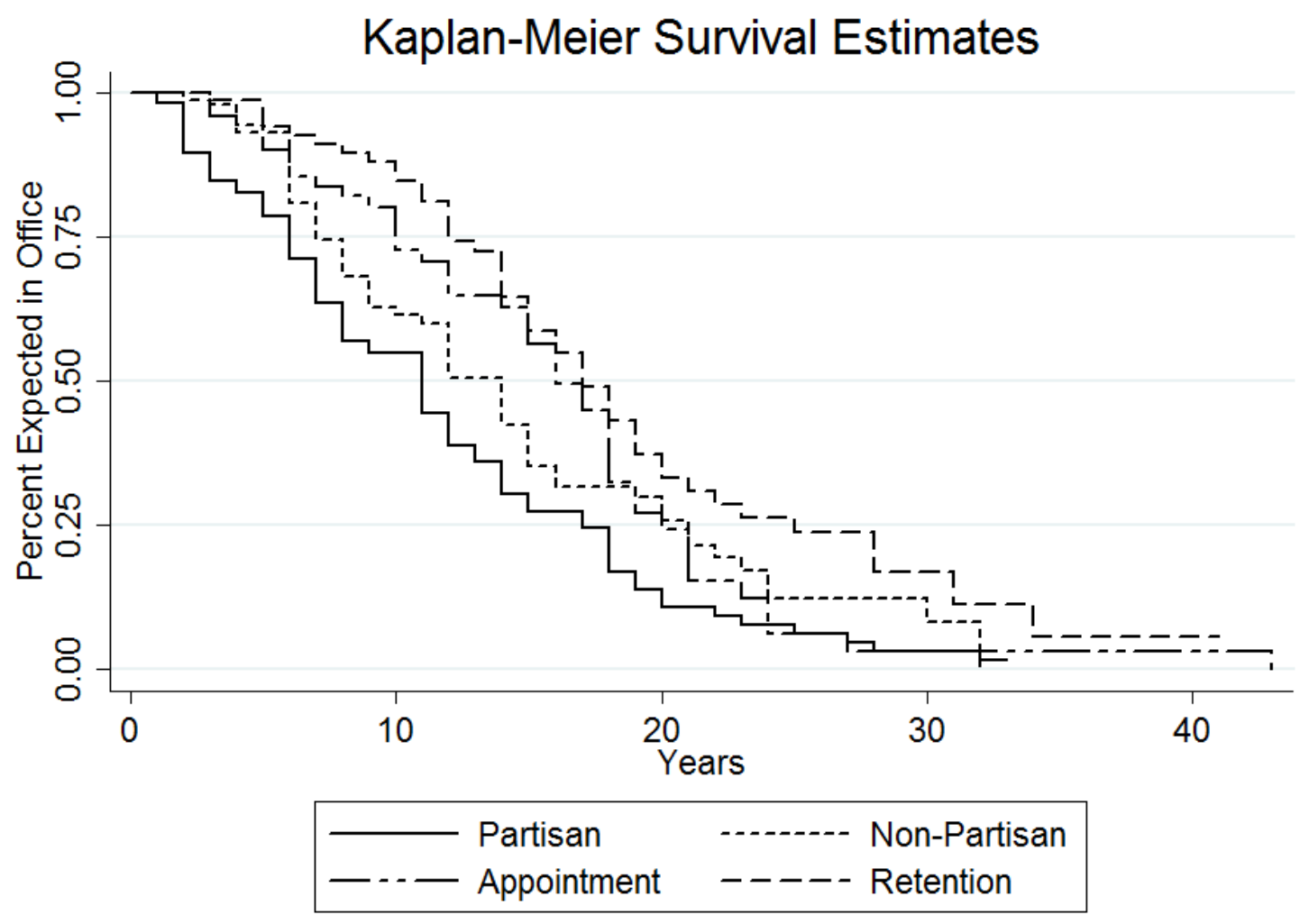

In our Cox model we exclude the Partisan Election variable, which serves as the baseline hazard rate. For purposes of interpretation, a variable with a negative coefficient signifies that it decreases the hazard rate, while a positive coefficient connotes that variable increases the hazard rate. Stated differently, a negative coefficient indicates a decreasing likelihood of a justice leaving the bench when compared to the baseline hazard, while a positive coefficient suggests an increasing likelihood the justice will leave the bench relative to the baseline hazard rate (see Table 1 for specific expectations).

Table 4 displays the results of our Cox model on the duration of judicial tenure of State as a function of selection and retention system. All three of the substantive variables, Nonpartisan Election, Appointment, and Retention Election, obtain statistical significance and are negatively signed, such that they each decrease the hazard rate. Two of the control variables, Age at Selection and the TVC Ideological Distance are statistically significant and positively signed, signifying that both of these variables increase the hazard rate, while Retirement Age, Gender, and Minority do not reach statistical significance. 
With respect to the substantive variables of interest, these findings signify that when compared to the baseline hazard rate of partisan elections, justices in all other selection systems experience longer careers. That is, these systems elicit a decrease in the hazard rate, which corresponds directly to a decrease in the level of distributed risk to justices subject to nonpartisan elections, appointments, or retention elections. These results support our theoretical expectations.

Table 4. Cox Proportional Hazard Model of the Duration of Tenure of State Supreme Court Justices as a Function of Selection and Retention System.

\begin{tabular}{lcc|}
\hline \hline Variable & Estimate (s.e) & Change in Hazard Rate \\
\hline \hline Nonpartisan Election & $-.628(.212)^{* *}$ & $-87 \%$ \\
Appointment & $-1.03(.267)^{* *}$ & $-180 \%$ \\
Retention Election & $-1.37(.242)^{* *}$ & $-293 \%$ \\
Retirement Age & $-.164(.165)$ & $-17 \%$ \\
Age at Selection & $.095(.014)^{* *}$ & $9.9 \%$ \\
Gender & $.005(.251)$ & $.5 \%$ \\
Minority & $.444(.239)$ & $55 \%$ \\
Ideological Distance & $.001(.000)^{*}$ & $1.1 \% * *$ \\
$* \mathrm{p} \leq .05 * * \mathrm{p} \leq .01$ & & \\
$* *$ Statistic calculated with Ideological Distance variable at its mean, and with a one standard deviation change. \\
Log Likelihood $=-1071.6641$ & \\
$\mathrm{LR} \chi^{2}=417.79$ & \\
Prob $>\chi^{2}=0.00$ & & \\
$\mathrm{~N}=3213$ & & \\
Scaled Schoenfeld residual global test $\mathrm{p}>\chi^{2}=0.12$ &
\end{tabular}

As for the control variables, the results show that the older justices are when they join the bench, the more quickly they leave it. Moreover, as the ideological distance between the justice and her constituency increases, the greater the likelihood that justice will depart the bench sooner than otherwise, irrespective of selection system, an intuitive but vital finding. Neither retirement age, gender status, nor minority status exert any influence on the duration of judicial tenure.

The hazard model provides additional information, as we can use the statistics from the model to rank order the different selection mechanisms in terms of the hazard rate, and thus risk, they produce. In particular, the last column of Table 4 depicts the proportional change in the baseline hazard rate for each variable. The interpretation is intuitive, in that a negative percentage signifies that, when compared to justices who stand for partisan elections, justices in states with that specific selection method are less likely to leave the bench, while a positive outcome indicates they are more likely to depart relative to partisan election justices. Accordingly, we find that justices in nonpartisan election systems are 87 percent less likely to leave the bench than justices in partisan systems, while appointed justices are 180 percent less likely to depart than partisan election justices. Finally, justices subject to retention elections are 
293 percent less likely to exit the bench than justices subject to partisan elections. Apparently, retention elections do not function like their more competitive counterparts, as justices in the Missouri Plan are nearly twice as unlikely to relinquish the bench for any reason compared to justices retained in partisan elections. This provides additional evidence in support of our theory that partisan elections, as they were designed, offer the most risk, while retention elections supply the least.

Finally, Figure 3 plots the hazard rates for the methods of selection and retention, thus enabling graphical comparison of the length of judicial careers produced by these mechanisms. To reiterate, the higher the hazard function then the more risk that selection system poses to judicial tenure; conversely, the lower the hazard rate the more insulated from risk are those justices. This figure illustrates that the system with the highest hazard rate, and thus the shortest judicial tenure, is partisan elections. Indeed, no other institution produces a hazard rate even relatively close, implying once again that partisan elections afford the most accountability. The method with the second highest hazard rate belongs to nonpartisan elections, as justices subject to these competitive elections experience longer tenures than those in partisan elections but shorter than the other systems. Figure 3 also reveals that appointive systems produce shorter tenures than retention elections. That is, the system with the lowest hazard rate, and thus the slightest degree of risk, is the Missouri Plan. In fact, justices subject to partisan elections have a higher risk of departing the bench in their fifth year in office than retention election justices have in their 15 th year on the bench. Clearly, the risk to judicial careers is far lower for justices in retention elections than for justices in any other selection system. 
Figure 3. Cox Proportional Hazard Rates of the Duration of Tenure of State Supreme Court Justices as a Function of Selection and Retention System.

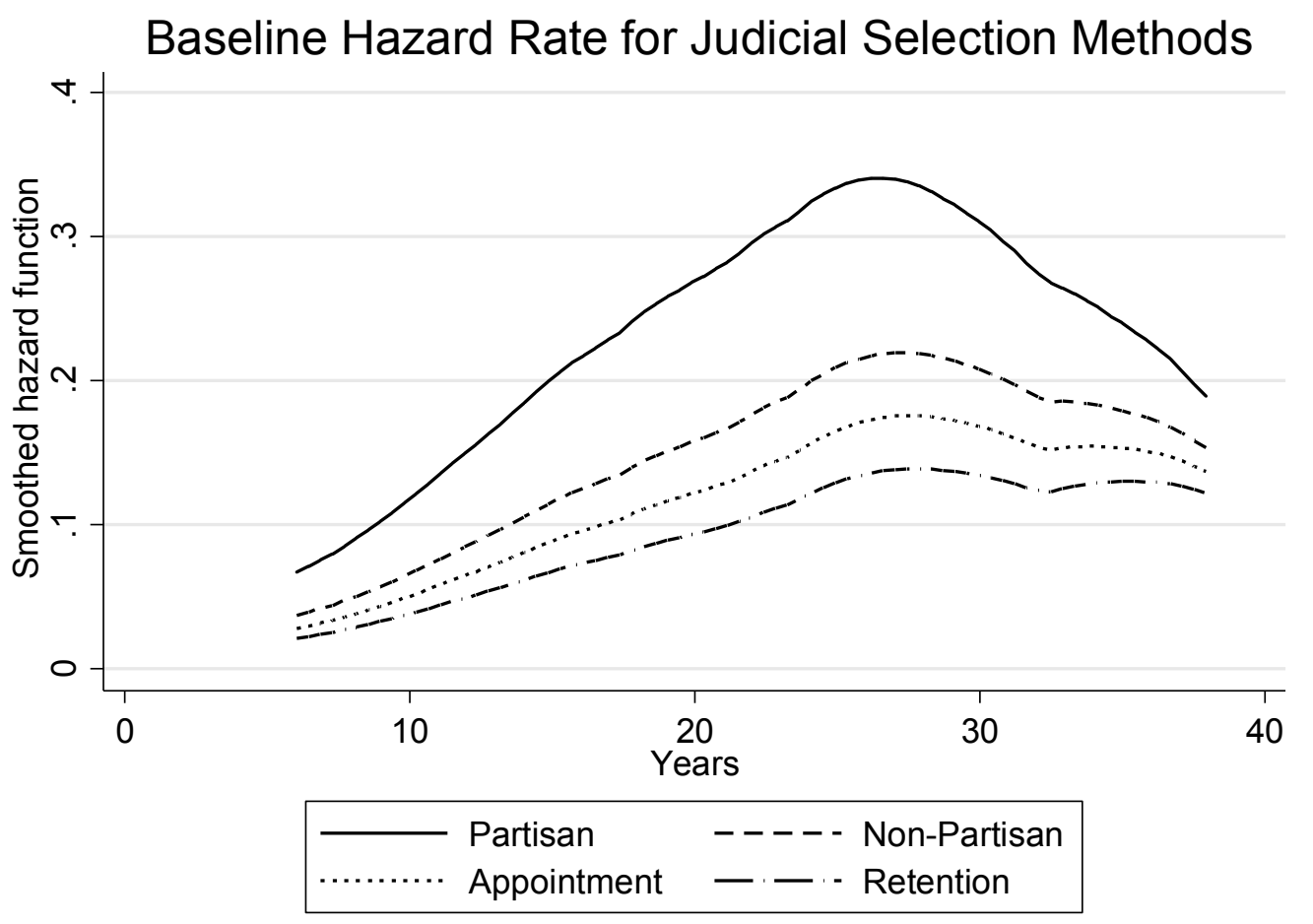

\section{Conclusions on Judicial Careers and Accountability}

The findings from the empirical analysis largely support our theoretical contention that the level of risk to judicial careers is a function of institutional variation in the states. More particularly, we posited that the several systems of selection and retention should present varying degrees of risk to supreme court justices, which would be detected by dissimilar but predictable lengths of tenure among the justices subject to these selection mechanisms. Both the descriptive results and those from the Cox hazard models are consistent with our expectations.

As well, we exhibit that partisan and nonpartisan electoral systems allocate the most risk to judicial careers. In this regard, justices in partisan elections have the shortest tenures and the highest departure rates relative to justices in other systems; that is, partisan elections produce high rates of turnover, and justices facing partisan election depart the court faster than those in any other selection method. Clearly, our research shows that partisan elections hold the greatest risk to the careers of state supreme court justices. Moreover, while nonpartisan electoral methods offer significantly more risk than either retention elections or appointive systems, that risk is not quite as great as with partisan elections.

Where do retention elections and appointive systems fit in to this schema? Our research design enabled us to test competing hypotheses with respect to these systems. We posited that appointive systems should produce relatively more risk than retention elections since retention elections are non-competitive institutions, whereas appointed justices who run counter to the preferences of their appointing body are subject to a certain degree of risk to their careers. To the 
contrary, judicial reform groups would expect that retention elections provide more risk than appointive systems, since retention elections, after all, are still elections; as well, appointments are designed to produce independent but not necessarily accountable judges (e.g., Hamilton, Federalist No. 78). On this point the results support our hypothesis, as justices in appointive systems have shorter judicial careers than those judges in the Missouri Plan. Thus, the evidence comports with our hypothesized rank order of selection systems, as justices in appointive systems face significantly more risk than those in non-competitive retention elections.

With respect to the states we examined that employ retention elections, only one justice was removed by the voters in 122 retention elections over 25 years of our analysis; moreover, the average judicial tenure was significantly longer with retention elections than with any other method of selection. The American Judicature Society (2010) has claimed the institution of retention election "provides an opportunity to remove from office those who do not fulfill their judicial responsibilities." Apparently, opportunity is not necessarily the equivalent of action, as our findings evince that retention elections produce but a trivial amount of risk to judicial careers.

In this study we contend there is a relationship between the amount of risk of removal from the bench and judicial accountability. As such, we employed the length of judicial tenure as a way of operationalizing this concept. That is, the more risk a selection and retention system posed to judicial careers, the shorter the tenure and, thus, the greater the degree of accountability established by that selection system.

Judicial selection mechanisms are in flux through the United States. Numerous states have either changed, or considered changing their methods of selection and retention within the past ten years. At the writing of this study, Kansas is contemplating changing from the Missouri Plan to an appointive system (Eveld 2016). The findings of our study seek to inform these debates. Under this analysis, if judicial accountability is the primary goal with respect to state courts of last resort, our findings suggest that the Missouri Plan's retention elections are not a wise choice. Simply put, justices subject to the Missouri Plan face minimal risk to their careers, as this system offers relatively little accountability. However, if judicial independence is the overriding objective, then retention elections provide the most effective mechanism for maximizing this goal. On the other hand, if a state hopes to maximize accountability, then it would do very well to employ partisan elections. While these findings and conclusions are somewhat consistent with those of other scholars, particularly Bonneau and Hall (2009) and Hall (2001), our research adds nuance to the literature on judicial selection in the states (see also Curry and Hurwitz N.d.). More particularly, no other study has incorporated a research design such as ours that observes judicial tenure as a proxy for accountability, nor has any employed event history models to test the nature of accountability in state supreme courts. Indeed, our Cox hazard models proved especially well-suited to analyzing the varying levels of risk among state supreme courts.

We do not take a position regarding which may be best or most appropriate selection system. Instead, our aim was to assess assumptions within the debate regarding accountability and risk by subjecting various assumptions to rigorous empirical testing. In that endeavor, we believe we have been successful. Perhaps our most interesting finding is that retention elections produce far less accountability than previously presumed. That is, any contention that retention 
elections produce levels of risk approaching competitive elections is not borne out by our findings. Consequently, the occurrence in Iowa 2010 should be recognized for what it is: a notable outlier. In fact, at this stage Iowa 2010 does not even appear to have set a trend, as not a single justice in the country was removed by a retention election in the 2012 or 2014 electoral cycles.

Our study attempts to ascertain whether tenure length and accountability vary as a function of institutional arrangements in state supreme courts. The findings support an answer in the affirmative, as judicial careers apparently are influenced by the institutional design of the various selection and retention systems. While it may have been assumed that that methods of selection could be rank-ordered by level of accountability, our approach incorporating event history models to analyze the length of judicial careers proved very capable in doing so. Thus, we have followed Hall's (2001) plea for further research by examining the nexus of democratic processes and institutional design regarding selection and retention of justices in state courts of last resort. There remains much to study with respect to this heated debate that touches upon normative and empirical claims. We hope that scholars will continue rigorous theoretical grounding and empirical examination regarding the influence of the several judicial selection and retention mechanisms on careers and accountability in state courts.

Acknowledgements: We are grateful to the following individuals for helpful comments at various stages of this project: Chris Bonneau, Brent Boyea, Paul Brace, Kevin Corder, Melinda Gann Hall, Lisa Holmes, Robert Howard, Bert Kritzer, Ashlyn Kuersten, Drew Lanier, Meghan Leonard, Kirk Randazzo, Michael Romano, Joseph Ross, and Jason Windett. We also thank our anonymous reviewers for their feedback. We presented previous versions of this research at the 2010 and 2011 American Political Science Association meetings. 


\section{References}

American Bar Association. (2003). Justice in Jeopardy: Report of the Commission on the 21st Century Judiciary. Chicago, IL: American Bar Association.

American Judicature Society. (2010). Merit Selection: The Best Way to Choose the Best Judges. American Judicature Society. http://www.judicialselection.us/uploads/documents/ ms_descrip_1185462202120.pdf (last viewed February 6, 2013).

Ansolabehere, Stephen, Iyengar, Shanto, Simon, Adam, \& Nicholas Valentino. (1994). "Does Attack Advertising Demobilize the Electorate?" American Political Science Review 88: 829-38.

Baum, Larry \& David Klein. (2007). "Voter Responses to High-Visibility Judicial Campaigns." In Running for Judge: The Rising Political, Financial, and Legal Stakes of Judicial Elections, edited by Matthew Streb, 140-64. New York: New York University Press.

Berkson, Larry C. (1980). "Judicial Selection in the United States: A Special Report." Judicature 64: 176-93.

Berry, William D., Ringquist, Evan J., Fording, Richard C. \& Russel L. Hanson. (1998). "Measuring Citizen and Government Ideology in the American States, 1960-93." American Journal of Political Science 42: 327-48.

Bonneau, Chris W. (2005). "Electoral Verdicts: Incumbent Defeats in State Supreme Court Elections." American Politics Research 33: 818-41.

Bonneau, Chris W. \& Damon Cann. (2011). "Campaign Spending, Diminishing Marginal Returns, and Campaign Finance Restrictions in Judicial Elections.” The Journal of Politics 73: 1267-80.

Bonneau, Chris W., and Damon M. Cann. 2015. Voters' Verdicts: Citizens, Campaigns, and Institutions in State Supreme Court Elections. Charlottesville: University of Virginia Press.

Bonneau, Chris W. \& Melinda Gann Hall. (2009). In Defense of Judicial Elections. New York: Routledge.

Box-Steffensmeier, Janet M., \& Bradford S. Jones. (2004). Event History Modeling: A Guide for Social Scientists. New York: Cambridge University Press.

Box-Steffensmeier, Janet M., \& Christopher J.W. Zorn, C. (2001). "Duration Models and Proportional Hazards in Political Science." American Journal of Political Science. 45: 972-88.

Brace, Paul, \& Brent D. Boyea. (2008). "State Public Opinion, the Death Penalty, and the Practice of Electing Judges.” American Journal of Political Science 52: 360-372.

Brace, Paul, \& Melinda Gann Hall. (1990). "Neo-Institutionalism and Dissent in State Supreme Courts." The Journal of Politics 52: 54-70.

Brace, Paul, Langer, Laura, \& Melinda Gann Hall. (2000). "Measuring the Preferences of State Supreme Court Judges.” The Journal of Politics 62: 387-413.

Burden, Barry C., Canon, David T., Lavertu, Stephane, Mayer, Kenneth R. \& Donald R. Moynihan. 2013 "Selection Method, Partisanship, and the Administration of Elections." American Politics Research 41: 903-936. 
Caufield, Rachel Paine. (2007). "Judicial Elections: Today's Trends and Tomorrow's Forecast." Judges'Journal 46: 6-11.

Caufield, Rachel Paine. (2012). "Inside Merit Selection: A National Survey of Judicial Nominating Commissioners." (Des Moines, IA: American Judicature Society) http:// www.judicialselection.us/uploads/documents/

JNC_Survey_ReportFINAL3_92E04A2F04E65.pdf (last viewed February 11, 2013).

Clark, Tom S. (2011). The Limits of Judicial Independence. New York: Cambridge University Press.

Collett, David. (2003). Modelling Survival Data in Medical Research. Boca Raton: CRC Press.

Cox, D. R. (1972). "Regression Models and Life Tables.” Journal of the Royal Statistical Society, Serial B. 34:187-220.

Curry, Todd A., and Mark S. Hurwitz. N.d. "Strategic Retirements of Elected and Appointed Justices: A Hazard Model Approach.” The Journal of Politics (forthcoming).

Downs, Anthony. (1957). An Economic Theory of Democracy. New York: Harper and Row.

Dubois, Philip. (1979). "Voter Turnout in State Judicial Elections: An Analysis of the Tail on the Electoral Kite." The Journal of Politics. 41: 865-87.

Dubois, Philip. (1980). From Ballot to Bench: Judicial Elections and the Quest for Accountability. Austin: University of Texas Press.

Eveld, Edward M. 2016. "Kansas House Debates Changing the Supreme Court selection process." The Kansas City Star.

http://www.kansascity.com/news/government-politics/article58197618.html (last viewed February 15, 2016)

Gibson, James L. (2009). “"New Style’ Judicial Campaigns and the Legitimacy of State High Courts." The Journal of Politics 71:1285-1304.

Gibson, James L. (2012). Electing Judges: The Surprising Effects of Campaigning on Judicial Legitimacy. Chicago: University of Chicago Press.

Glick, Henry. \& Kenneth Vines. (1973). State Court Systems. Englewood Cliffs, NJ: PrenticeHall.

Graves, Scott E., Howard, Robert M., \& Corley, Pamela C. 2014. "Judicial Independence: Evidence from a Natural Experiment.” Law \& Policy 36: 68-90.

Hall, Melinda Gann. (1995). "Justices as Representatives: Elections and Judicial Politics in the American States." American Politics Quarterly, 23: 485-503.

Hall, Melinda Gann. (2001). "Voluntary Retirements from State Supreme Courts: Assessing Democratic Pressures to Relinquish the Bench." The Journal of Politics 63: 1112-40.

Hall, Melinda Gann. (2007a). "Voting in State Supreme Court Elections: Competition and Context as Democratic Incentives." The Journal of Politics, 69: 1147-1159.

Hall, Melinda Gann. (2007b). "Competition as Accountability in State Supreme Court Elections." In Running for Judge: The Rising Political, Financial, and Legal Stakes of Judicial Elections, edited by Matthew Streb, 165-85. New York: New York University Press.

Hall, Melinda Gann. 2015. Attacking Judges: How Campaign Advertising Influences State Supreme Court Elections. Stanford: Stanford University Press. 
Hall, Melinda Gann, \& Chris W. Bonneau. (2006). "Does Quality Matter? Challengers in State Supreme Court Elections.” American Journal of Political Science 50: 20-33.

Hall, Melinda Gann. \& Chris W. Bonneau. (2008). "Mobilizing Interest: The Effects of Money on Citizen Participation in State Supreme Court Elections." American Journal of Political Science 52: 457-70.

Hall, Melinda Gann. \& Chris W. Bonneau. (2013). "Attack Advertising, the White Decision, and Voter Participation in State Supreme Court Elections.” Political Research Quarterly 66: 115-26.

Hamilton, Alexander, James Madison, and John Jay. (1990 [1787]). The Federalist Papers. George Carey and James McClellan (eds.). Dubuque, IA: Kendell/Hunt.

Haynes, Evan. (1944). The Selection and Tenure of Judges. Newark: National Conference on Judicial Councils.

Hurwitz, Mark S., \& Drew Noble Lanier. (2008). "Diversity in State and Federal Appellate Courts: Change and Continuity Across 20 Years." Justice System Journal 29: 47-70.

Klein, David \& Larry Baum. (2001). "Ballot Information and Voting Decisions in Judicial Elections." Political Research Quarterly. 54: 709-28.

Kritzer, Herbert M. 2015. Justices on the Ballot: Continuity and Change in State Supreme Court Elections. New York: Cambridge University Press.

Langer, Laura. (2002). Judicial Review in State Supreme Courts: A Comparative Study. Albany: State University of New York Press.

Langer, Laura, McMullen, Jody, Ray, Nicholas P. \& Stratton, Daniel D. (2003). "Recruitment of Chief Justices on State Supreme Courts: A Choice between Institutional and Personal Goals." The Journal of Politics. 65: 656-75.

O'Connor, Sandra Day. (2003). The Majesty of the Law: Reflections of a Supreme Court Justice. New York: Random House.

Patton, Dana. (2007). "The Supreme Court and Morality Policy Adoption in the American States: The Impact of Constitutional Context." Political Research Quarterly 60: 468-88.

Shugerman, Jed Handelsman. (2012). The People's Courts: Pursuing Judicial Independence in America. (Cambridge: Harvard University Press).

Savchak, Elisha Carol, Thomas G. Hansford, Donald R. Songer, Kenneth L. Manning, and Robert A. Carp (2006). "Taking It to the Next Level: The Elevation of District Court Judges to the U.S. Courts of Appeals. American Journal of Political Science 50: 478-93.

Shipan, Charles R. and Megan L. Shannon. (2003). "Delaying Justice(s): A Duration Analysis of Supreme Court Nominations.” American Journal of Political Science. 47: 654-68.

Streb, Matthew J. (2007). "The Study of Judicial Elections.” In Running for Judge: The Rising Political, Financial, and Legal Stakes of Judicial Elections, edited by Matthew Streb, 1-14. New York: New York University Press.

Vanderleeuw, James M. \& Richard L. Engstrom. (1987). "Race, Referendums, and Roll-Off." The Journal of Politics 49: 1081-92.

Varnum v. Brien. 2009. 763 N.W.2d 862 (Iowa).

Wheat, Elizabeth, \& Mark S. Hurwitz. (2013). "The Politics of Judicial Selection: The Case of the Michigan Supreme Court." Judicature 96: 178-88. 